\title{
Corruption, Terrorism and the Stock Market: The Evidence from Iraq
}

\author{
Zeravan Abdulmuhsen ASAAD ${ }^{1}$, Bayar MohamedRasheed MARANE ${ }^{2}$
}

Received: August 01, 2020 Revised: September 06, 2020 Accepted: September 10, 2020

\begin{abstract}
The current study explains how corruption, terrorism, political stability and oil price has an effect on on the Iraq stock exchange utilizing corruption perception index as a proxy of corruption, global terrorism index as proxy for terrorism, political stability and oil price with ISX60 index as proxy of stock market for the period (2005-2019) using Ordinary Least Square method. The results show that the level of corruption, terrorism activities and political stability coefficient is significantly positive with Iraq stock exchange. In contrast, the oil price coefficient is significantly negative with Iraq stock exchange, which means that lower levels of corruption, less terrorism activities and more stability in political system have strong influence on stock market development in Iraq. The study concludes that the explanatory variables are important for Iraq stock exchange. Hence, the study suggests the policy makers to develop stock market by implementing policies and strategies to overcome high level of corruption, terrorism activities especially after ISIS/ISIL announcement has been made public. There is a need for transparency and creating stable political environment through good governance practices in order to attract more foreign investment and promote economic development. Factors like terrorism and corruption make economic and political systems unstable and has an adverse effect on on Iraq's stock exchange performance.
\end{abstract}

Keywords: Iraq Stock Exchange, Corruption, Terrorism, Political Stability, Oil Price

JEL Classification Code: D53, D73, P48, G12

\section{Introduction}

The financial market refers to a set of facilities, arrangements and institutional procedures for providing lending and borrowing by non-financial economic units, and it plays the role of financial intermediaries in order to facilitate the process of transferring funds for medium and long term. Iraq is still considered a country which is at high levels of political risk in international classifications by institutions which are specialized in risk assessment for the study period ranging (2004-2018). This means that the impact of the

${ }^{1}$ First Author and Corresponding Author. Assistant Professor, Department of Business Administration, Cihan University - Duhok / University of Duhok, Kurdistan Region - Iraq [Postal Address: 38 Zakho Road,1006AJ Duhok, Kurdistan Region - Iraq]

Email: zeravan.asaad@uod.ac

${ }^{2}$ Assistant Professor, Department of Business Administration, Cihan University - Duhok / University of Duhok, Kurdistan Region - Iraq. Email: bayar.marane@uod.ac

(c) Copyright: The Author(s)

This is an Open Access article distributed under the terms of the Creative Commons Attribution Non-Commercial License (https://creativecommons.org/licenses/by-nc/4.0/) which permits unrestricted non-commercial use, distribution, and reproduction in any medium, provided the original work is properly cited. degree of political turmoil on the business environment was high and there was presence of government interference in private sector, this situation is an important political risk and a major determinant of the economic growth and foreign direct investment (Asaad, Marane \& Mustafa, 2020).

A lot of studies have been concentrated on the potential linkages among various factors affecting the development of stock market in many contexts in dissimilar regions. Recently, some of these studies investigated in one way or another, the influence of corruption (Aljazaerli, Sirop \& Mouselli, 2016; Asaad, Marane \& Mustafa, 2020; Ming, Jais, Ab Rahim \& Che-Ahmed, 2018; Missaoui, Brahmi \& Rajeb, 2018; Modugu \& Dempere, 2020; Ojeka et al., 2019; Shahbaz, H. \& Shabbir, 2013), terrorism (Arif \& Suleman, 2014; Arin, Ciferri \& Spagnolo, 2008; Bilal, Talib \& U1 Haq, 2012; Alam, 2013; Christofis, Kollias, Papadamou \& Stagiannis, 2013; Gadhoum, Aldawsari \& Almusbeh, 2017; Geyikci \& Tepeci, 2017; Hadhek, Halfaoui \& Lafi, 2019; Hassan, Mahmood, Ahmed \& Abbas, 2014; Kollias, Manou, Papadamou \& Stagiannis, 2011; Moussa \& Talbi, 2019; Nguyen \& Enomoto, 2009; Zaiane, 2018), political stability (Abdelbaki, 2013; Asaad \& Marane, 2020; Chau, Deesomsak \& Wang, 2014; Chen, Bin \& Chen, 2005; Cherif 
\& Gazdar, 2010; Girma \& Shorland, 2008; Gunay, 2016; Modugu \& Dempere, 2020; Moussa \& Talbi, 2019; Yartey, 2008; Zaiane, 2018) or oil price (Berk \& Aydogan, 2012; Bjornland, 2009; Creti, Ftiti \& Guesmi, 2013; Eryigit, 2009; Hammoudeh \& Li, 2005; Marane, 2015; Mustafa, 2020; Nguyen, Nguyen \& Nguyen, 2020; Oskooe, 2011) on the development of stock market. However, these results are still inconsistent and non-consensus. Apart from the above, little interest was given to the influence of corruption, terrorism, political stability or oil price on stock market development in Iraq as a key player in the international oil market because of the fact that it ranks as the fifth largest oil reserves in the world; Also the fact that Iraq is considered as one of the richest countries in Middle East and North Africa (MENA) region. In spite of that, Iraq is still facing challenges of high level of corruption, less transparency, terrorism activities and violence especially after ISIS announcement has being public. All these factors make economic and political system unstable and has an adverse effect on on Iraq stock exchange performance.

There are only a few studies which concentrates on Iraq stock exchange, most of these previous studies have ignored Iraq stock exchange and Palestinian stock markets which is considered as a limitation in the MENA region sample (Asaad, 2014; Asaad, Marane \& Omer, 2015). Hence, this study provides a cove to the gap which exist in those studies related to the coverage of the Iraq stock exchange. Therefore, the main aim of study is to test the influence of corruption, terrorism, and political stability on Iraq stock exchange utilizing corruption perception index as a proxy of corruption, global terrorism index as proxy for terrorism, political stability with oil price and general index which was derived from 60 companies as proxy of stock market for the period (2005-2019) using ordinary least square. In general, this study is very essential to contribute to the current argument of the role of level of corruption, terrorism activities and instability of political system and oil prices in stock price movement, and it is important for regulators with local and foreigner investors who wish to invest in stock exchange in Iraq as an oil exporting country. The rest of the paper have been structured as: literature review and hypotheses in part two, methodology and model specification have been mentioned in part three while the results and analysis have been discussed in part four and finally conclusion have been presented in part five.

\section{Literature Review and Hypotheses}

The potential association between the levels of corruption, terrorism activities, and stability in the political system and oil price on the stock exchange have been studied differently and there has been no consensus at all within the literature concerning the context, methodology and techniques.
Nevertheless, The Arab Spring (2011) as a revolution or civil uprising which started in Tunis (Zaiane, 2018) and the emergence of terrorist groups such as Islamic State in Iraq and Syria (ISIS/ISIL) after (2014) which the number of terrorist activities increased globally (Asaad, Marane \& Mustafa, 2020). Subsequently, the crude oil prices declined sharply, followed by chaos and instability in political system spread in different developing countries especially in the Middle-East. All these factors have led to a growing demand for research on the subject of direct or indirect economic cost and consequences of corruption, terrorism, political system and oil price.

There are many empirical studies related to the determinants of stock exchange progress in developing countries (Cherif \& Gazdar, 2010; Moussa \& Talbi, 2019). Several of the previous studies have concentrated on the determinants of stock market performance in developed and developing countries based on the Arbitrage Pricing Theory (APT) which showed that the stock market was effected by many factors (Asaad, 2017), and the first study employed this theory to estimate United State stock returns for the period (1953-1984) (Chen, Roll \& Ross, 1986).

\subsection{Corruption and Stock Market}

A lot of studies have explored the influence of corruption on stock markets and have received a big attention (Missaoui et al., 2018), in spite of the fact that the studies are still ongoing and persistent in the literature to be attributed to the fact that this relationship remains inconsistent and ambiguous (Aljazaerli et al., 2016; Ojeka et al., 2019).

However, various studies have found that the level of corruption can have an adverse effect on the stock market. A study which employed the data of ten Asian countries for the period (2003-2015) found a significant influence of some macroeconomics variables and corruption perception index on the stock market performance. Therefore, investors should consider the level of change on corruption before making any decisions (Ming et al., 2018). Furthermore it showed that the corruption has a significant negative influence on the TobinQ and return on asset (ROA) for (135) listed companies for the period (2013-2017) in Nigeria (Ojeka et al., 2019), parallel to a study pointed out that the corruption is statistically negatively insignificant and does not appear to be forced for (14) stock market in (MENA) region for the period (Cherif \& Gazdar, 2010). Same results are consistent with the empirical works done by employing a panel data of (42) emerging countries for the period (1990-2004) (Yartey, 2008).

On contrary, numerous studies support the viewpoint of precipitation of corruption, speeding the business and economic growth (Missaoui et al., 2018). A study clarified a significant positive influence of corruption level on the stock 
market for a sample of (20) listed companies for the period (2006-2016) (Aljazaerli et al., 2016; Missaoui et al., 2018). In addition, another study focused on Gulf Cooperation Council (GCC) as a special case of relatively high level of corruption for the period (2003-2011), as the findings show a positive influence of corruption on stock market development, which is consistent with the view that corruption can speed up the progress of transactions and stimulate the economy (Aljazaerli et al., 2016). Furthermore, another study used ARDL approach, cointegration and causality tests for the period (1987-2009), the findings discovered that the ascent level of corruption has a positive effect on financial development in Pakistan (Shahbaz et al., 2013), likewise a study explored that the control of corruption level has a positive and significant impact on the foreign investments inflows in Iraq (Asaad, Marane \& Mustafa, 2020).

As a whole, it is general consensus that states with higher levels of corruption lead to lower growth rate with public policy ineffectiveness and foreign direct Investment inflows are less interested to invest in corrupted states. The current study hypothesis is based on the Republic of Iraq characteristics and previous studies which relatively focused on the relationships between corruption and stock market in various context, to discuss this case, the following hypothesis can be drawn from the prior discussion.

$\boldsymbol{H}_{1}:$ The influence of corruption on Iraq stock Exchange is expected to be negative.

\subsection{Terrorism and Stock Market}

Numerous empirical studies have found an influence of terrorism activities on the stock market around the world. In general, stock market declines from terrorist activities and make investors unwilling to keep their business in case of unpredictable future events (Geyikci \& Tepeci, 2017). Moreover, terrorism events produce uncertainty and high risk for investments which adversely influence the financial markets then decreasing economic growth (Moussa \& Talbi, 2019).

A study conducted in Turkey found that the Istanbul stock market is significantly affected by terrorist attacks (Christofis et al., 2013; Geyikci \& Tepeci, 2017), while a study analyzed in Pakistan showed that terrorism activities negatively influenced Karachi stock exchange (Alam, 2013; Bilal et al., 2012). Also, another study in the same context exhibited positive and negative significant influence of terrorism activities on stock market sectors (Arif \& Suleman, 2014; Hassan et al., 2014). While a study explored the relationship between the terrorism activities within the United Kingdom and the Greece stock market. Its results indicated that the Greece stock market is more susceptible to terrorism activities compared to the United Kingdom stock market. Hence, small stock market is more sensitive to terrorism activities (Kollias et al., 2011). Another study conducted the impact of terrorism activities on six different financial markets and the results show that both stock markets and the stock market volatility were significantly affected by terror actions. In addition, the bulk of these impacts are bigger in emerging markets (Arin et al., 2008), whereas a study found that some of international stock markets can be affected by terrorism activities which were in the year (2016) immediately but in short-range only (Gadhoum et al., 2017). Same results were also found in Iran and Pakistan stock markets (Nguyen \& Enomoto, 2009).

Besides, a study showed a strong influence of terrorism acts on the behavior of ten sectorial stock indices return to Tunisian benchmark index (TUNINDEX) using the daily data for the period (2010- 2016) (Zaiane, 2018). Moreover, a study used daily data for two sub periods before and after revolution and the output shows that the terror acts affect the performance and volatility of the Tunisian market performance especially after the revolution (Moussa \& Talbi, 2019). After all, the above findings are confirmed by another study done on twelve stock markets which were divided into developed, emerging and frontier market for the period (2008-2015) with global terrorism index (GTI). The study dedicated that terror has an immediate negative influence on all stock markets in the short term and the stock market recorded the same reaction in the long term (Hadhek et al., 2019). As a whole, terrorist activities create direct passive effect on investors and business environment in a country. Therefore, the study hypothesis constructed is based on the Iraq characteristics and previous studies which are relatively concentrated on the effect of terrorism on the financial stock exchange in various contexts. To discourse this case, the following hypothesis can be drawn from the prior discussion.

$\boldsymbol{H}_{2}:$ The influence of terrorism on Iraq stock exchange is expected to be negative.

\subsection{Political Stability and Stock Market}

Overall, the good governance and political stability attract capital to the state, increasing market share to achieve a desirable level of economic development and better business environment (Asaad \& Marane, 2020). Consequently, the stability of state political system becomes one of the interesting topics and is considered one of the determinants of the financial markets in the emerging and developing countries (Cherif \& Gazdar, 2010; Modugu \& Dempere, 2020; Moussa \& Talbi, 2019; Yartey, 2008). According to the investors' and researcher's viewpoint, political risk is an effectual factor for pricing asset (Chen et al., 2005). There are many studies contributed to previous literature which has 
investigated the impact of stability on political system on the financial market performance.

A study verified that the democracy and political stability are significant variables to financial development using panel data for the period (1975-2000) in developed and developing countries (Girma \& Shorland, 2008). Differently a study revealed that the political risk index has a negative and insignificant influence on stock market development in (14) MENA countries for the period (1990-2007), which means that political risks are strongly related to growth of capitalization of stock market (Cherif \& Gazdar, 2010). Likewise, a work has given that price reactions of stock performance in Taiwan to bulk of the political events are rather insignificant, thus the findings assist local and foreign institution investors to well understand and analyze the political risk for investing in Taiwanese stock market (Chen et al., 2005). A work detected that some macroeconomic variables and political risks are significant and strongly associated with the growth in stock market capitalization, thus these are main determinants of (42) stock market development using (GMM) estimation for a panel data for the period (1990-2004) (Yartey, 2008). Moreover, a work showed that all indices return to Tunisian benchmark index are not affected by the political news using the daily data for the period (2010- 2016) (Zaiane, 2018).

Whereas, a study confirmed that the political instability had a strong influence on the stock market performance and fell sharply after Arab Spring / revolution in Egypt using a vector error correction between the period of March to November 2011 (Abdelbaki, 2013). Also a study has found that the volatility of Islamic indices becomes higher during political uncertainty caused in the Arab countries by civil uprisings period with no influence at all on the volatility of conventional indices using daily closing prices multivariate $(\mathrm{GARCH})$ model and on the volatility of major MENA stock markets for the period (2009-2012) of total (805) observation (Chau et al., 2014). While a study used daily data for two sub periods before and after revolution and the output revealed that the political instability affected the Tunisian market performance and volatility especially after the revolution and also the returns decreased and it increased the volatility of the index (Moussa $\&$ Talbi, 2019). In addition, another study concluded that the Turkish stock market reacted with political events but not significantly using various techniques to obtain beaks and regimes in the Turkish index return volatilities during the period (2001-2014) (Gunay, 2016). In general, investors prefer stable state in business environment in a democratic system. Based on this, the study hypothesis has been developed on Republic of Iraq characteristics, the previous studies had relatively focused on the terrorism on the financial stock exchange in various contexts. To discuss this case, the following hypothesis can be drawn from the previous discussion.
$\boldsymbol{H}_{3}:$ The influence of political stability on Iraq stock exchange is expected to be positive.

\subsection{Oil Price and Stock Market}

Modern trends in economic and financial studies have discussed the link between the oil price and the stock prices, also different results can be traced to different nature of the country, whether it is a supplier or exporter of crude oil. Most of these studies were conducted in developed oil importing countries (Eryigit, 2009), but recently its importance has increased for the oil exporting countries, as it is the main source of the state budget through which it influences the performance of financial markets (Echchabi \& Azouzi, 2017; Marane, 2015).

A study in Turkey showed a weak influence of crude oil price change on the stock market by employing a (VAR) model using daily data for Brent crude and the Istanbul Stock Exchange index (ISE-100) for the period (1990- 2011) (Berk \& Aydogan, 2012), while in the same context, another study found that there is a positive impact of oil prices on some sectors in the Istanbul Stock Exchange (Eryigit, 2009). Another study found that the rise of Brent crude as a measure of oil prices leads to higher return on Norwegian shares, and that the Norwegian economy responds to oil price rises by increasing total wealth and demand using the VAR model on monthly data for the stability period of the Norwegian monetary system (1993-2005) (Bjornland, 2009). Another study concluded that some of Gulf countries stock markets (Qatar, Oman, UAE) are positively affected by oil prices using daily observations for the year (2005), also study in Vietnam showed the positive effect of tow oil price indices Brent and west Texas Intermediate on the two stock market indices using the daily observation for the period (2000-2019) (Nguyen et al., 2020), these results confirmed the negative significant effect of oil price with Iraq stock exchange for the period (2005-2018) (Mustafa, 2020).

A study was conducted in Iran to test the dynamic relationship between oil prices and the stock market for weekly data for the period (1999-2010), and concluded that the variation in oil prices does not cause any variation in share prices, bearing the absence of any impact of the international oil markets on the Iranian stock market (Oskooe, 2011). Meanwhile, a mixed study attempted to find the degree of overlap between oil prices and stock market indicators in a group of importing and exporting oil using monthly data for the period (2000-2010). Then the results showed that the overlap between oil prices and stock markets is higher in the oil exporting countries compared to the importing countries (Creti et al., 2013). The study aimed to test and compare the sensitivity of oil by using West Texas Intermediate on the return of the daily shares of four 
international capital markets for the period (1986-2003) and found that the growth of oil prices drives the shares return of oil exporting countries and US industries, while showing more sensitivity to the US oil sector, and the systemic risk is of greater importance compared to the sensitivity of oil in pricing stocks (Hammoudeh \& Li, 2005).

Based on the above, studies one can conclude that there are a few studies on this topic in context of Iraq (Marane \& Asaad, 2014). Specially the instability of economic and political systems, terrorism activities and sectarian conflict, high level of corruption are characterized in the environment of the country since (2003), these characteristics are the main obstacles faced by foreign direct investment flows into Iraq after invasion by the United States and its allies in (2003) (Asaad, 2014). Iraq depends on crude oil $(95 \%)$ as the only source for the country which leads to its reflection in economy as a result of the market fluctuations (Asaad, Mustaf \& Saleem, 2020).

Overall, the increase in oil prices will have an affirmative effect on the domestic economy of the oil-exporting countries. Based on that, the study hypothesis constructed was dependent on the characteristics of Iraq as a country as well as the previous studies which relatively focused on the oil price on Iraq stock exchange in various contexts. To discourse this case, the following hypothesis can be drawn from the above discussion.

$\boldsymbol{H}_{4}:$ The influence of oil price on Iraq Stock Exchange is expected to be positive.

\section{Methodology}

\subsection{Objective of the Study}

The objective of the study is to investigate the potential effects of corruption, terrorism, political stability and oil price on the Iraq stock exchange index for the period (2005-2019).

\subsection{Variable Definitions \& Data Sources}

Iraq Stock Exchange Index (ISXI) is a general index which is derived from 60 companies that Iraq Stock
Exchange has chosen from a cross-section of the total listed companies in Iraq, which is calculated from 2014 based on X-stream technique; the ISX60 replaced the general index of ISX (Iraq Stock Exchange, Annual report 2019).

The Corruption Perceptions Index measures the comprehensive level of corruption and is considered as an indicator of perceptions of administrative and political corruption in the public sector. The value of index is specified and collected from public sector surveys. Furthermore, the index with higher value presents lower corruption and vice versa. Where, the index value is between (0) and (10) (Ming et al., 2018).

Global Terrorism Index indicates a general expansion of terrorism activities and events e.g. attach. This index is a composition of fatalities, injuries, incidents, property damaged directly or indirectly resulting from terrorism in 162 countries in the world (Arif \& Suleman, 2014; Hadhek et al., 2019). Overall, the index with higher value produces high terrorism acts and vice versa and the index value is between (0) and (1).

Political stability is a sub dimension of Composite Governance Indicators (CGI) which measures and captures the likelihood of government change or violence threats and expressed as the extent to which a government is stable (Asaad \& Marane, 2020; Modugu \& Dempere, 2020).

The oil price measures the crude oil price per barrel using West Texas Intermediate (WTI) as proxy for oil price in the study. This measurement is used by many of the previous studies (Nguyen et al., 2020) and the measurement is correlated strongly with other measurements such as Brent or OPEC. Iraq is a principal member in oil petroleum exporting countries (OPEC), so the oil price plays an essential role in the exporting country and any increase in the oil prices will lead to an increase in the economic growth to become very good tools that explains any change in stock market. Generally, the oil price changes have significant effects on the real economic activity and employment. In addition to this, oil price changes and shocks are very important devices to explain stock price changes (see Table 1).

Table 1: Variables Measurements and Data Sources

\begin{tabular}{|l|l|c|l|}
\hline Variable & \multicolumn{1}{|c|}{ Measurement } & Acronym & \multicolumn{1}{c|}{ Data Source } \\
\hline $\begin{array}{l}\text { Stock Exchange } \\
\text { Index }\end{array}$ & $\begin{array}{l}\text { Logarithm of the General } \\
\text { Index of Iraq Stock Exchange }\end{array}$ & LISXI & Iraq Stock Exchange Annual Report \\
\hline Corruption & Corruption Perception Index & CPI & Transparency International Organization Annual Report \\
\hline Terrorism & Global Terrorism Index & GTI & Institute for Economics and Peace (IEP) Annual Report \\
\hline Political Stability & Index of Political Stability & IPS & The World Bank \\
\hline Oil Price & WTI crude oil price per barrel & OP & U.S Energy Information Administration Database \\
\hline
\end{tabular}




\subsection{Scope of the study}

This empirical study utilizes annual time series data for the period (2005-2019) in the Republic of Iraq. The index of stock exchange is used as the dependent variable with corruption, terrorism, political stability and oil price as four independent variables.

\subsection{Model Specification}

The framework of the empirical study combines the stock market and corruption, terrorism, political stability and oil price using the Ordinary Least Square technique and evaluates the results of the regression according to some assumptions. In addition, it employs the normality and multicollinearity tests, and the equation of the study model is as follows:

Estimation Command: LS LISXI CPI GTI PS OP C

Estimation Equation: LISXI $=\mathrm{C}(1) * \mathrm{CPI}+\mathrm{C}(2) * \mathrm{GTI}+$ $\mathrm{C}(3) * \mathrm{PS}+\mathrm{C}(4) * \mathrm{OP}+\mathrm{C}(5)$

$\mathrm{Y}=\beta 0+\beta 1(\mathrm{CPI})+\beta 2(\mathrm{GTI})+\beta 3(\mathrm{PS})+\beta 4(\mathrm{OP})+\mathrm{E}$

Where Y denotes the dependent variable, which represents a logarithm of stock exchange index which is defined as the LISXI, $\beta 0$ is intercept of the model. Corruption Perception index (CPI), Global Terrorism Index (GTI), Political Stability (PS) and Oil Price (OP) are the independent variables. $\beta 1$, $\beta 2, \beta 3$ and $\beta 4$ are the parameters in the model and the $E$ denotes the error term disturbances.

\section{Results and Analysis}

\subsection{Preliminary Test}

The current study employs Jarque-Bera (JB) test for normality, table (2) exhibits that all variables (LISXI, CPI,
GTI, PS and OP) in the model are normally distributed to the probability value to be less than (5\%). Also, the study employs Variance Inflation Factor (VIF) test for multicollinearity, which exhibits that there is no multicollinearity among the independent variables (CPI, GTI, PS and OP) due to the Centered VIF value which is less than (3) for all the variables. That is good for regression model (Gujarati \& Porter, 2009). Besides, correlations matrix confirmed that there was no multicollinearity among the independent variables. Therefore, the study is healthy in term of normality and multicollinearity (see Table 2).

\subsection{Descriptive Statistics}

The study time series movements for the period (2005-2019) are presented in figure (1) for a total of (15) observations. Also, table (3) presents the descriptive statistics which shows for example that the mean of (LISXI) is (4.983158). The standard deviation is (1.124335) and so on for all independent variables with minimum, maximum, median, Skewness and Kurtosis values (see Figure 1 and Table 3).

\subsection{Regression Model}

Table (4) presents that the significant positive coefficient is $(0.212,21.27,1.625)$ for (corruption perception index, global terrorism index and political stability) respectively, which means that every point enhancement in (CPI, GTI and PS) leads to an increase of nearly $(21.27 \%, 160 \%, 28.28 \%)$ respectively in the Iraq stock exchange index and vis-à-vis. Also, the results find out that the statistically non-significant coefficient for oil price indicates that oil price does not have an effect on stock exchange in Iraq since the probability value is greater than $(5 \%)$.

Table 2: Normality, Variance Inflation Factor Test and Correlation Matrix

\begin{tabular}{|l|c|c|c|c|c|}
\hline Test & LISXI & CPI & GTI & PS & OP \\
\hline Jarque-Bera Test & 1.051466 & 0.341400 & 1.884332 & 0.490702 & 1.559730 \\
\hline Probability & 0.591122 & 0.843074 & 0.389783 & 0.782430 & 0.458468 \\
\hline $\begin{array}{l}\text { Variance Inflation } \\
\text { Factor Test }\end{array}$ & - & 2.068980 & 2.908881 & 2.518732 & 2.588523 \\
\hline Correlation & & & & & \\
\hline LISXI & 1.000000 & & & & \\
\hline CPI & 0.107637 & 1.000000 & & & \\
\hline GTI & 0.757036 & -0.480034 & 1.000000 & & 1.000000 \\
\hline PS & 0.471875 & -0.158216 & 0.434466 & & \\
\hline OP & -0.393006 & -0.309181 & -0.153241 & 0.476759 & 1.000000 \\
\hline
\end{tabular}


Zeravan Abdulmuhsen ASAAD, Bayar MohamedRasheed MARANE /

$\operatorname{LISXI}$

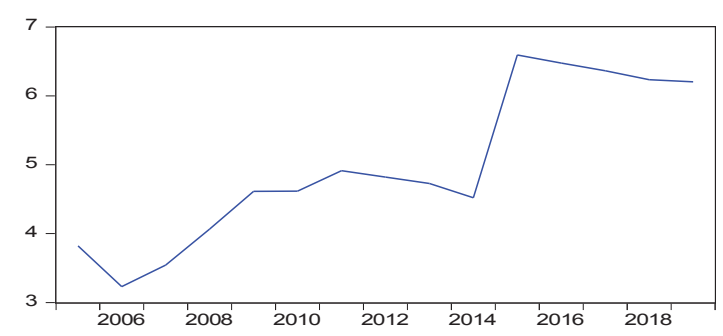

GTI

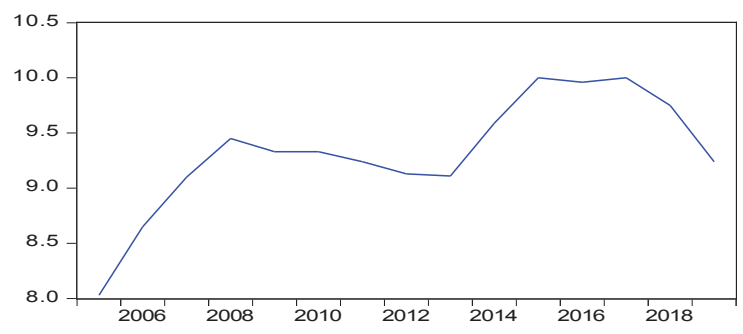

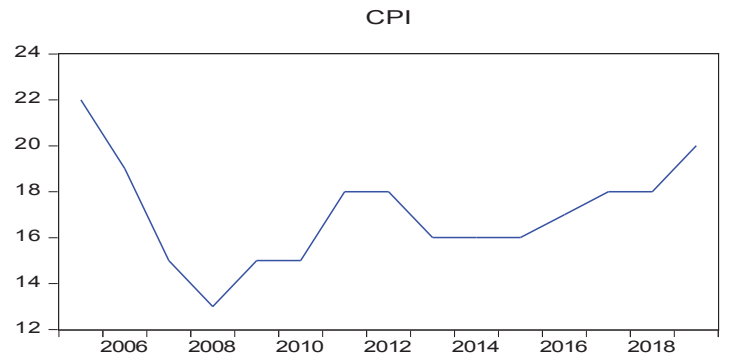

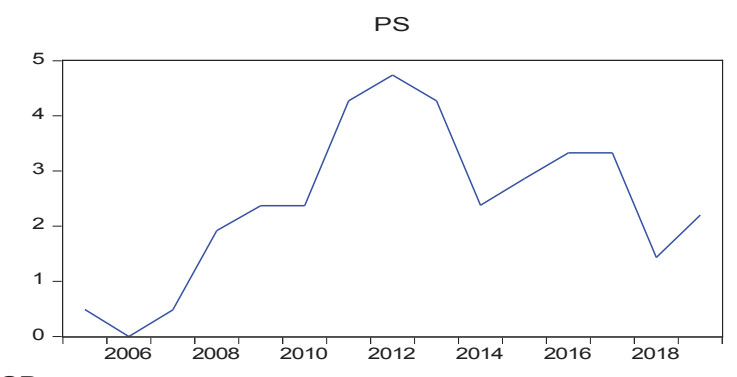

OP

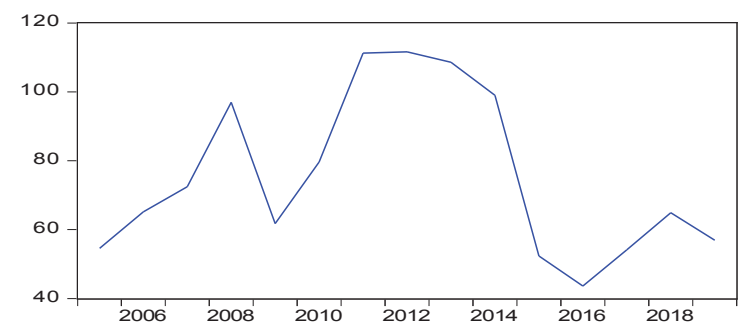

Figure 1: Study Variables Movements for the Period (2005-2019)

Table 3: Descriptive Statistics

\begin{tabular}{|l|c|c|c|c|c|}
\hline & LISXI & CPI & GTI & PS & OP \\
\hline Mean & 4.983158 & 17.06667 & 9.327333 & 2.429333 & 75.51800 \\
\hline Median & 4.728714 & 17.00000 & 9.330000 & 2.370000 & 65.16000 \\
\hline Maximum & 6.593811 & 22.00000 & 10.00000 & 4.740000 & 111.6300 \\
\hline Minimum & 3.230409 & 13.00000 & 8.030000 & 0.000000 & 43.64000 \\
\hline Std. Dev. & 1.124335 & 2.282438 & 0.525282 & 1.431929 & 23.77810 \\
\hline Skewness & 0.155102 & 0.363191 & -0.799793 & -0.096452 & 0.419960 \\
\hline Kurtosis & 1.740587 & 2.863585 & 3.675470 & 2.135181 & 1.662053 \\
\hline Sum & 74.74737 & 256.0000 & 139.9100 & 36.44000 & 1132.770 \\
\hline Sum Sq. Dev. & 17.69782 & 72.93333 & 3.862893 & 28.70589 & 7915.570 \\
\hline Observations & 15 & 15 & 15 & 15 & 15 \\
\hline
\end{tabular}


Table 4: Regression Results of LISXI with CPI, GTI, PS and OP

\begin{tabular}{|l|c|c|c|c|}
\hline \multicolumn{4}{|c|}{ Dependent Variable (LISXI): Method (Least Square): Sample 15 observations (2005-2019) } \\
\hline Variable & Coefficient & Std. Error & t-Statistic & Prob. \\
\hline CPI & 0.212772 & 0.065218 & 3.262462 & 0.0085 \\
\hline GTI & 1.625878 & 0.336017 & 4.838684 & 0.0007 \\
\hline PS & 0.282898 & 0.114699 & 2.466440 & 0.0333 \\
\hline OP & -0.014887 & 0.007002 & -2.125974 & 0.0594 \\
\hline C & -13.37630 & 4.175673 & -3.203387 & 0.0094 \\
\hline R-squared & 0.915280 & F-statistic & 27.00882 & \\
\hline Adjusted R-squared & 0.881391 & Prob(F-statistic) & 0.000024 & \\
\hline Durbin-Watson stat & \multicolumn{4}{|l}{} \\
\hline
\end{tabular}

The regression model shows that the corruption perception index coefficient values are significant at (5\%), this finding seems to be consistent with some prior studies which are expected and would satisfy the theoretical viewpoint that high corruption has a negative effect on the stock market due to the investors who are not interested to invest in a corrupted state (Ming et al., 2018; Ojeka et al., 2019). Nevertheless, the study results about corruption are not similar to some other past studies which reveal that the level of corruption is precipitated and speeds up the business and economic growth (Aljazaerli et al., 2016; Shahbaz et al., 2003; Missaoui et al., 2018). Hence the study cannot reject the first hypothesis.

However, the regression model shows that the global terrorism index coefficient values are significant at (5\%). Here, the study cannot reject the second hypothesis. The result of the regression model regarding terrorism is in agreement with theoretical viewpoint and with some of the past studies (Alam, 2013; Arin et al., 2008; Bilal et al., 2012; Christofis et al., 2013; Gadhoum et al., 2017; Geyikci \& Tepeci, 2017; Hadhek et al., 2019; Kollias et al., 2011; Moussa \& Talbi, 2019; Nguyen \& Enomoto, 2009; Zaiane, 2018) that terrorist activities create direct converse impact on investors and state business environment. However, this study results appear differently with some other studies (Arif \& Suleman, 2014; Hassan et al., 2014).

Also, the regression model shows that the political stability index coefficient values are significant at (5\%). This output accept the third hypothesis which is in compatibility with the theoretical viewpoint and with some previous studies (Abdelbaki, 2013; Asaad \& Marane, 2020; Chau et al., 2014; Girma \& Shorland, 2008; Modugu \& Dempere, 2020; Moussa \& Talbi, 2019; Yartey, 2008) in that political tensions and turmoil has an effect on the stability of stock market, despite that these results are inconsistent with some other past studies (Chen et al., 2005; Cherif \& Gazdar, 2010; Gunay, 2016; Zaiane, 2018).
The regression model shows that the oil price coefficient values are insignificant at (5\%). These results are in contrast with some previous studies (Berk \& Aydogan, 2012; Bjornland, 2009; Creti et al., 2013; Echchabi \& Azouzi, 2017; Eryigit, 2009; Hammoudeh \& Li, 2005; Marane, 2015; Mustafa, 2020 ) in that an increase in the oil prices will have a positive effect on the oil-exporting countries due to the an increase in their income, and consequently leading to an increase in their spending and investments. This follows with an increase in the productivity and lowering of unemployment. These results are coinciding with some of the prior works (Nguyen et al., 2020; Oskooe, 2011), accordingly the study can reject the fourth hypothesis (see Table 4).

In addition, the $\mathrm{R}^{2}$ is (91.5\%) and adjusted $\mathrm{R}^{2}$ is $(88.1 \%)$ which point out that it is good-fit of regression equation and the value denotes that about $(88.1 \%)$ of the variations in dependent variable are explained by the variations in the independent variable. Also, the model is fit back to significant of F-statistics at (1\%). The outcome equation can be expressed mathematically as:

$$
\begin{aligned}
& \text { LISXI }=-13.3762+0.2127 * \mathrm{CPI}+1.6258^{*} \mathrm{GTI} \\
& +0.2828 * \mathrm{PS}-0.0148 * \mathrm{OP}
\end{aligned}
$$

\subsection{Model Evaluation}

In short, the regression model results are free from serial correlation, free from heteroskedasticity and residuals are in normal distribution. Table (5) shows that the residuals follow the hypothesis of the (normal distribution) because the probability is greater than $(5 \%)$ for value $(0.65)$. Also, it shows the results of Breusch-Godfrey serial correlation LM test cannot reject the null hypothesis and the residuals are free from serial correlation based on non-significant of probability of Chi-Square greater than (5\%) (see Table 5).

In that manner, the table (5) finds out that the errors are free of heteroskedasticity according to the ARCH test 
Zeravan Abdulmuhsen ASAAD, Bayar MohamedRasheed MARANE /

Journal of Asian Finance, Economics and Business Vol 7 No 10 (2020) 629-639

Table 5: Normality, Serial Correlation and Heteroskedasticity Test Results

\begin{tabular}{|c|c|c|}
\hline \multicolumn{3}{|l|}{ Normality Test: } \\
\hline Jarque-Bera & Prob. & 0.722522 \\
\hline \multicolumn{3}{|c|}{ Breusch-Godfrey Serial Correlation LM Test: } \\
\hline F-statistic & Prob. F $(1,9)$ & 0.6067 \\
\hline Obs*R-squared & Prob. Chi-Square (1) & 0.4978 \\
\hline \multicolumn{3}{|c|}{ Heteroskedasticity Test: ARCH } \\
\hline F-statistic & Prob. F $(1,12)$ & 0.2565 \\
\hline Obs ${ }^{*}$-squared & Prob. Chi-Square (1) & 0.2236 \\
\hline \multicolumn{3}{|c|}{ Heteroskedasticity Test: Breusch-Pagan-Godfrey } \\
\hline F-statistic & Prob. F $(4,10)$ & 0.1626 \\
\hline Obs*R-squared & Prob. Chi-Square (4) & 0.1490 \\
\hline Scaled explained SS & Prob. Chi-Square (4) & 0.8312 \\
\hline
\end{tabular}

non-significant p-value Chi-square of (0.2236). Also, this finding has been trustworthy by Breusch-Pagan-Godfrey for White Heteroskedasticity test. Then this study cannot reject the null hypothesis of homoscedasticity of residual which is depended on the non-significant probability value of Chi-square (0.1490). In addition, exhibit shows the CUSUM test which is based on the cumulative sum of the recursive residuals, it finds parameter stability because the cumulative sum is kept inside the area between the two critical lines.

\section{Conclusion}

The current paper has examined the effect of corruption, terrorism, political stability and oil price on the Iraqi stock exchange for the period (2005-2019) using ordinary least square method. The finding from the regression model regarding (CPI, GTI and PS) shows that the coefficient values are significant at $(5 \%)$. Hence, it indicates that the study cannot reject the hypothesis $\left(\mathrm{H}_{1}, \mathrm{H}_{2}, \mathrm{H}_{3}\right)$. Differently, each point increase in each of the three explanatory variable which is associated with an increase of Iraq stock exchange index. In addition, the study only rejects the hypothesis of oil price related to Iraq stock exchange. These results appear to be consistent in one way or another with prior studies (Abdelbaki, 2013; Alam, 2013; Arin et al., 2008; Asaad \& Marane, 2020; Berk \& Aydogan, 2012; Bilal et al., 2012; Bjornland, 2009; Chau et al., 2014; Christofis et al., 2013; Creti et al., 2013; Eryigit, 2009; Gadhoum et al., 2017; Geyikci \& Tepeci, 2017; Girma \& Shorland, 2008; Hadhek et al., 2019; Hammoudeh \& Li, 2005; Kollias et al., 2011; Marane, 2015; Ming et al., 2018; Moussa \& Talbi, 2019; Mustafa, 2020; Nguyen \& Enomoto, 2009; Ojeka et al., 2019; Yartey, 2008; Zaiane, 2018).

The findings reveal that the levels of corruption, terrorism activities and political stability are significant predictors of Iraq stock exchange, referring that when the business environment in Iraq is stated as being more corrupt and less transparent, facing terrorism activities with presence of more violence and public possibility of destabilization, have a negative effect on the Iraq stock exchange performance. Hence, findings confirmed the adverse effect of corruption, terrorism and political instability on Iraq stock exchange performance.

In general, this study results are considered as a part of the augmenting literature on the linkage between corruption, terrorism, political stability and oil price with stock price. In brief, the study findings are very essential in contributing to the current argument about the role of levels of corruption, terrorist activities leading to instability of political system and oil price in stocks pricing movement. They are important to regulators with local and foreigner investors who wish to invest in Iraq stock exchange as an oil exporting country. Further study evidence suggests that high corruption, terrorism events and political tension and oil price change can make the instability of financial markets even worse.

\section{Limitation and Further Studies}

Mentioning the limitations of the study, the first limitation is the generalization which is bound to the available annual data to each of corruption perception index, global terrorism index and political stability index. The study has only an annual measure whick would have only (15) times series points for the period (2005-2019), which are deemed insufficient for econometric analysis. The second limitation is that the current study has used only the general index of Iraq stock exchanges and does not cover the index of stock market sectors because many changes happened recently and made it difficult to study the sector level of stock market. Third limitation is the possibility to consider other factors 
that may affect the stock markets, such as pandemic of Covid-19, changes in the gold price or exchange rate, the influence of wars, and political tension of other neighboring countries over Iraq.

For further studies, since Iraq is facing different challenges of terrorism activities with high level of corruption in government and poor governance with instability of political system in last two decade, it needs more studies to focus on the stock market response to different unexpected political events such as elections, number of lives lost, injury and damage to property from terrorism attacks, crime or even sectarian on stock market fluctuation. In addition, future studies give more attention to the dissimilarity of measurement types as proxy of corruption, terrorism, political stability and oil price, besides extend the context of study to include other countries in the region and benefit from specialty of embracing longer period.

\section{References}

Abdelbaki, H. (2013). The impact of Arab Spring on stock market performance. British Journal of Economics, Management \& Trade, 3(3), 169-185. https://doi.org/10.9734/bjemt/2013/3768.

Alam, A. (2013). Terrorism and stock market development; causality evidence from Pakistan. Journal of Financial Crime, 20(1), 116-128. https://doi.org/10.1108/13590791311287364.

Aljazaerli, M. A., Sirop, R., \& Mouselli, S. (2016). Corruption and stock market development: New evidence from GCC countries. Business Theory \& Practice, 17(2), 117-127. https:// doi.org/10.3846/btp.2016.555.

Arif, I., \& Suleman. T. (2014). Terrorism and stock market linkages: An empirical study from Pakistan. MPRA Munich Personal RePEc Archive. https://mpra.ub.uni-muenchen.de/58918/1/ MPRA_paper_58918.pdf

Arin, K. P., Ciferri, D., \& Spagnolo, N. (2008). The price of terror: The effects of terrorism on stock market returns and volatility. Economics Letters, 101(3), 164-167.

Asaad, Z. (2017). The Influence of the Financial and Real Output Indicators on Malaysian Stock Market. Cihan International Journal of Social Science, 1(1), 4-21.

Asaad, Z. A. (2014). Testing the bank sector at weak form efficiency in Iraq Stock Exchange for period (2004-2014): Empirical research. Journal of Economic Sciences, 10(37), 57-80. https:// www.iasj.net/iasj?func $=$ fulltext\&aId $=101154$.

Asaad, Z. A., \& Marane, M. (2020). The Influence of Human Development, Institutional Quality and ISIS Emergence on Foreign Direct Investment in Iraq. Technium Social Sciences Journal, 10(1), 318-332. https://techniumscience.com/index. $\mathrm{php} /$ socialsciences/article/view/1402

Asaad, Z. A., Marane, M. O., \& Mustafa, H. M., (2020). The impact of Geopolitical Risks and the Human Development on Foreign Direct Investment Inflows in Iraq for the Period (2004-2018). Global Journal of Business and Economics, 9(1).
Asaad, Z., Marane, B. M., \& Omer, A. (2015). Testing the efficiency of Iraq Stock Exchange for period (2010-2014): An empirical study. Journal of University of Duhok, 17(1), 192-217.

Asaad, Z., Mustafa, H. M., \& Saleem, A. M. (2020). The impact of FDI Inflows on GDP Growth in Iraq for the period (20042017): An applied study. Journal of Tanmiat Al-Rafidain. [In Press].

Berk, I., \& Aydogan, B. (2012) Crude oil price shocks and stock returns: Evidence from Turkish stock market under global liquidity conditions (No. 12/15). EWI Working Paper. Available at https://www.econstor.eu/ obitstream/10419/74397/1/746639147.pdf.

Bilal, A. R., Talib, N. A., Ul Haq, I., Khan, M. N., \& Islam, T. (2012). How terrorism and macroeconomic factors impact on returns: A case study of Karachi stock exchange. World Applied Sciences Journal, 19(11), 1575-1584. doi: 10.5829/idosi. wasj.2012.19.11.2611.

Bjornland, H. C. (2009). Oil price shocks and stock market booms in an oil-exporting country. Scottish Journal of Political Economy, 56, 232-254. https://doi.org/10.1111/j.14679485.2009.00482.x.

Chau, F., Deesomsak, R., \& Wang, J. (2014). Political uncertainty and stock market volatility in the Middle East and North African (MENA) countries. Journal of International Financial Markets, Institutions \& Money, 28, 1-19. https://doi.org/10.1016/j. intfin.2013.10.008.

Chen, D., Bin, F., \& Chen, C. (2005). The impacts of political events on foreign institutional investors and stock returns: Emerging market evidence from Taiwan. International Journal of Business, 10(1), 165-188.

Chen, N., Roll, R., \& Ross, S. (1986). Economic forces and the stock market. Journal of Business, 59(3), pp. 383-403.

Cherif, M., \& Gazdar. K. (2010). Institutional and macroeconomic determinants of stock market development in MENA region: New results from a panel data analysis. International Journal of Banking and Finance, 7(1), 139-159. https://doi.org/10.32890/ ijbf2010.7.1.8403.

Christofis, N., Kollias, C., Papadamou, S., \& Stagiannis, A. (2013). Istanbul stock market's reaction to terrorist attacks. Dogus University Journal, 14(2), 153-164. https://doi.org/10.31671/ dogus.2018.103.

Creti, A., Ftiti, Z., \& Guesmi, K. (2013). Oil price impact on financial markets: Co-spectral analysis for exporting versus importing countries. EconomiX Working Papers 2013-11, University of Paris West.

Echchabi, A., \& Azouzi, D. (2017). Oil Price fluctuations and stock market movements: An application in Oman. Journal of Asian Finance, Economics and Business, 4(2), 19-86. http://dx.doi. org/10.13106/jafeb.2017.vol4.no2.1.

Eryigit, M. (2009). Effects of Oil Price Changes on the Sector Indices of Istanbul Stock Exchange. International Research Journal of Finance and Economics, 25, 209-216. 
Gadhoum, Y., Aldawsari, A., \& Almusbeh. H. (2017). The effect of terror events on financial markets. Asia Pacific Journal of Advanced Business and Social Studies, 3(2), 34-43.

Geyikci, U. B., \& Tepeci, M. (2017). The impacts of the Russian plane crisis, the July $15^{\text {th }}$ coup d'etat attempt and terrorist attacks on the market values of the Istanbul stock exchange (ISE) tourism index. International Journal of Arts \& Sciences, 10(01), 109-120.

Girma, S. \& Shortland, A. (2008). The political economy of financial development. Oxford Economic Papers, 60(4), 567-596. https://doi.org/10.1093/oep/gpm040.

Gujarati, D. N., \& Porter, D. C. (2009). Basic Econometrics. Boston, MA: McGraw-Hill Irwin.

Gunay, S. (2016). Is political risk still an issue for Turkish stock market?. Borsa Istanbul Review, 16(1), 21-31. https://doi. org/10.1016/j.bir.2016.01.003.

Hadhek, Z., Halfaoui, S., \& Lafi, M. (2019). Terrorism and stock market performance. International Research Journal of Finance and Economics, 171, 48-62.

Hammoudeh, S., \& Li, H. (2005). Oil sensitivity and systematic risk in oil-sensitive stock indices. Journal of Economics and Business, 57(1) 1-21. https://doi.org/10.1016/j. jeconbus.2004.08.002.

Hassan S. A., Mahmood, A., Ahmed, A., \& Abbas, S. F. (2014). Impact of Terrorism on Karachi Stock Exchange: Pakistan. Journal of Basic and Applied Scientific Research, 4(7), 182-191.

Kollias, C., Manou, E., Papadamou, S., \& Stagiannis, A. (2011). Stock markets and terrorist attacks: comparative evidence from a large and a small capitalization market. European Journal of Political Economy, 27(1), 564-577. https://doi.org/10.1016/j. ejpoleco.2011.05.002.

Marane, B. M., \& Asaad, Z. (2014). Analysis of the Bank's Ability which are Operating in the Kurdistan Region of Iraq to Meet the Investment Law. Economic Sciences, 9(35), 39-71. https:// www.iasj.net/iasj?func $=$ article\&aId $=88254$.

Marane. B. (2015). The impact of oil prices on the Iraq stock exchange for the period (2010-2014): An applied study. Journal of University of Duhok, 18(2), 535-554.

Ming, K. L., Jais, M., Abd Rahim, R., \& Che-Ahmed, A. (2018). Corruption and stock market development: Evidence from Asian countries. The Journal of Social Sciences Research, Special Issue 6, 357-362. https://doi.org/10.32861/jssr. spi6.357.362.

Missaoui, I., Brahmi, M., \& Rajeb, J. (2018). Quantitative relationship between corruption and development of the
Tunisian stock market. Public and Municipal Finance, 7(2), 39-47. https://doi.org/10.21511/pmf.07(2).2018.04.

Modugu, K. P., \& Dempere, J. (2020). Country-Level Governance Quality and stock market performance of GCC countries. Journal of Asian Finance, Economics and Business, 7(8), 185195. https://doi.org/10.13106/jafeb.2020.vol7.no8.185.

Moussa, F., \& Talbi, M. (2019). Stock market reaction to terrorist attachs and political uncertaintly: Empirical evidence from the Tunisian stock exchange. International Journal of Economics and Financial, 9(3), 48-64. https://doi.org/10.32479/ijefi.7968.

Mustaf, H. M. (2020). The Impact of Some Macroeconomic Variables in the General Index of the Iraqi Stock Exchange for the Period (2005-2018): An Empirical Study. Academic Journal of Nawroz University. (in press).

Nguyen, A. P., \& Enomoto, C. E. (2009). Acts of terrorism and their impacts on stock index returns and volatility: The cases of the Karachi and Tehran stock exchange. International Business and Economics Research Journal, 8(12), 75-86. https://doi. org/10.19030/iber.v8i12.3199.

Nguyen, T. N., Nguyen, D. T., \& Nguyen, V. N. (2020). The impacts of oil price and exchange rate on Vietnamese stock market. Journal of Asian Finance, Economics and Business, 7(8), 143-150. https://doi.org/10.13106/jafeb.2020.vol7.no8.143

Ojeka, S., Adegboye, A., Adegboye, K., Umukoro, O., Dahunsi, O., \& Ozordi. E. (2019). Corruption perception, institutional quality and performance of listed companies in Nigeria. Heliyon, 5, e02569, 1-10. https://doi.org/10.1016/j.heliyon.2019.e02569.

Oskooe, S. A. (2011). Oil price shock and stock market in an oilexporting country evidence from causality in mean and variance test. International Conference on Applied Economics, 443-451.

Shahbaz, M., Hye, Q. M. A., \& Shabbir, M. S. (2013). Does corruption increase financial development? A time series analysis in Pakistan. International Journal of Economics and Empirical Research, 1(10), 113-124.

Yartey, C. A. (2008). The determinants of stock market development in emerging economies: Is South Africa different? IMF Working Paper No.08/32. https://www.imf.org/en/Publications/ WP/Issues/2016/12/31/The-Determinants-of-Stock-MarketDevelopment-in-Emerging-Economies-Is-South-AfricaDifferent-21646

Zaiane, S. (2018). The impact of political instability driven by the Tunisian revolution on stock market volatility: Evidence from sectorial indices. The Journal of Applied Business Research, 34(2), 339-354. https://doi.org/10.19030/jabr.v34i2.10135. 